Jurnal Teknologi, 42(A) Jun. 2005: 13-26

(C) Universiti Teknologi Malaysia

\title{
WEATHER DOWNTIME AND ITS EFFECT ON FISHING OPERATION IN PENINSULAR MALAYSIA
}

\author{
OMAR YAAKOB $^{1} \&$ QUAH PENG CHAU ${ }^{2}$
}

\begin{abstract}
This paper presents the results of a study of the effect of weather downtime on the fishing industry in Peninsular Malaysia. The study was carried out with the aim of establishing a clearer relationship between weather and fishing operation, especially during monsoon season. This paper focused on the wind and wave pattern and their effects on fishing boat operability, fish landing, fish availability, and price. The effect on the fishermen activity and income as a result of the weather down time was also discussed. The result of the study has indicated that there is a close relationship between weather and fishing operation as well as fishermen's income. The study also concluded that weather has been significantly affecting the East Coast fishermen compared with their West Coast counterparts.
\end{abstract}

Keywords: Weather downtime, fishing boats, fishing operation, monsoon

\begin{abstract}
Abstrak. Kertas kerja ini membentangkan hasil kajian mengenai kesan cuaca ke atas industri perikanan di Semenanjung Malaysia. Kajian ini dilakukan dengan tujuan untuk menentukan perhubungan yang jelas antara operasi menangkap ikan dan cuaca terutama di musim tengkujuh. Kertas kerja ini difokuskan kepada corak ombak dan angin dan kesannya ke atas kebolehoperasian bot perikanan, tangkapan, kesediaadaan dan harga ikan. Kesan ke atas aktiviti nelayan dan pendapatan akibat cuaca buruk juga dibincangkan. Keputusan yang diperolehi menunjukkan pertalian rapat antara cuaca dan operasi menangkap ikan dan seterusnya pendapatan nelayan. Kajian ini juga menyimpulkan bahawa kesan cuaca lebih ketara bagi nelayan Pantai Timur berbanding nelayan Pantai Barat.
\end{abstract}

Kata kunci: Kesan cuaca, bot perikanan, operasi perikanan, tengkujuh

\subsection{INTRODUCTION}

Fishing is an important industry in Malaysia. In year 1996, the total production from the fisheries sector amounted to 1239434 tonnes valued at RM3.84 billion, constituting about $1.54 \%$ of the national Gross Domestic Product (GDP). Although the percentage is low compared with other sector economy, the fisheries sector in Malaysia still plays a significant role with regards to the provision of employment, especially in rural areas, and in the support it provides to economic growth. Most importantly, the fisheries sector provides the main source of protein for the nation and export potential.

$\overline{1 \& 2}$ Department of Marine Technology, Faculty of Mechanical Engineering, Universiti Teknologi Malaysia, 81310 UTM Skudai, Johor 
As a result of the Government's enactment of Exclusive Economic Zone (EEZ) Act in 1984, the fishermen are now given the right to fish in an area of 160000 square miles, compared with 4500 square miles in the past. In this circumstance, larger boats greater than 70 GRT are heading towards deep-sea fishing, while the area within 30 nautical miles is reserved for smaller boats. With the introduction of EEZ, fishing area has increased tremendously especially off the East Coast of Peninsular Malaysia.

Despite its longer beach line and wider open sea, the development of fishing industry in the East Coast is obviously slower. In 1996, the total landings of marine fish on the West Coast amounted to 519495 tonnes compared with only 288162 tonnes for the East Coast. One of the probable reasons is that, in the East Coast, there are still a lot of traditional fishermen unable to catch-up with technological development. As a result, many of these traditional boats are not able to go fishing as the operation of the smaller boats being used are very dependent on the weather condition. As such during the Monsoon season, they are unable to go out to the sea resulting in a decrease in the fish landings.

In an attempt to seek a better understanding of the relationship between the weather downtime and performance of the East Coast fishing industry, a study was carried out to quantify these effects. This study was carried out using fisheries data from Department of Fisheries Malaysia (DFM) [1], sea conditions data from Malaysian Meteorological Service (MMS) [2-4] while socio-economic data were taken from Fisheries Development Board (LKIM) [5]. Since complete weather data is available for the year 1996, fisheries data for the year 1996 was used in the analysis. The results of this study are presented in this paper.

\subsection{MALAYSIAN FISHING INDUSTRY}

According to the Annual Fisheries Statistics [1] in 1996, marine fisheries sector contributed 1126689 tonnes, or $90.9 \%$ of the total fisheries production, while aquaculture (excluding ornamental fish industry) contributed 109062 tonnes or 8.8\%, and the inland fisheries contributed 3683 tonnes or $0.3 \%$. In terms of value, the marine fisheries contributed RM 3.322 billion or $86.53 \%$, and aquaculture fisheries (including ornamental fish industry) contributed RM 0.517 billion or $13.47 \%$. The marine fisheries sector thus plays a major role in fisheries industry of Malaysia, while the inland fisheries does not contribute significantly to the industry.

Table 1 shows distribution of Marine fisheries landings in 1996. It indicates that the East Coast of Peninsula only contributed 26\% of the grand total, or 36\% of the Peninsula's landings, although it has a geological advantage of longer coastline and wider fishing areas. It can also be seen that Perak contributed nearly $20 \%$ of the nation's catch, and in terms of value exceeds that of the whole of the East Coast.

Table 2 shows the distribution of fishing vessel in Malaysia. It can be seen that trawlers predominate the commercial sector on the West Coast while on the East 
Table 1 Quantity and percentage of landings and value of marine fish by region in Malaysia

\begin{tabular}{lcccc}
\hline Area & Quantity (tonnes) & \% landing & Value (RM) & $\%$ value \\
\hline Peninsular West Coast & 519,495 & 46.11 & $1,797,955,551$ & 54.12 \\
Peninsular East Coast & 288,162 & 25.58 & $642,175,768$ & 19.33 \\
Sabah and Sarawak & 319,032 & 28.32 & $882,026,058$ & 26.55 \\
Total & $1,126,689$ & & $3,322,157,377$ & \\
\hline
\end{tabular}

Table 2 Number of licensed fishing vessels by states and gear group

\begin{tabular}{lrrrrrrr}
\hline State & $\begin{array}{c}\text { Trawl } \\
\text { net }\end{array}$ & $\begin{array}{c}\text { Fish } \\
\text { seine net }\end{array}$ & $\begin{array}{c}\text { Other } \\
\text { seine }\end{array}$ & $\begin{array}{c}\text { Drift/ } \\
\text { gill net }\end{array}$ & $\begin{array}{c}\text { Hook } \\
\text { \& line }\end{array}$ & Other & Total \\
\hline Perlis & 193 & 108 & 1 & 307 & 8 & 5 & 622 \\
Kedah & 488 & 15 & 61 & 898 & 11 & 53 & 1526 \\
P. Pinang & 96 & 27 & 52 & 1011 & 56 & 49 & 1291 \\
Perak & 1277 & 51 & 587 & 1989 & 118 & 400 & 4422 \\
Selangor & 742 & 16 & 4 & 1439 & 59 & 303 & 2563 \\
N. Sembilan & 0 & 0 & 1 & 160 & 6 & 7 & 174 \\
Melaka & 0 & 0 & 3 & 664 & 45 & 5 & 717 \\
West Johor & 267 & 0 & 8 & 2821 & 48 & 217 & 3361 \\
Kelantan & 86 & 34 & 45 & 701 & 165 & 41 & 1072 \\
Terengganu & 245 & 323 & 36 & 743 & 929 & 212 & 2488 \\
Pahang & 341 & 83 & 15 & 588 & 217 & 133 & 1377 \\
East Johor & 253 & 65 & 1 & 1102 & 141 & 75 & 1637 \\
\hline Sub-total & 3988 & 722 & 814 & 12423 & 1803 & 1500 & 21250 \\
\hline
\end{tabular}

Coast, commercial fishing is done from purse seiners. Data from [1] has shown that most of the fishing boats in Terengganu are small and 72\% of them are below 15 GRT. It has also been shown that Terengganu has the most number of fishermen in Peninsula Malaysia although the number of fishing boats is less than in Perak and Selangor, in the West Coast. These arise from the fact that in Perak and Selangor, most of the fishing boats are trawlers, while the purse seiners which employ more crew are popular in Terengganu. According to LKIM [5], for the same class of boat, seiner employs more crew than the other gear types, due to the nature of its operation. As an example, a 25 GRT trawler may require only 4 crews and a skipper to operate, while a seiner of the same size may require up to 14 crews, due to bigger manpower required to operate the gear. The detail comparison for other boat sizes is shown in Table 3. 
Table 3 Mean number of fishermen on board (including skipper) [5]

\begin{tabular}{lrrrr}
\hline GRT & $\mathbf{0 - 9 . 9}$ & $\mathbf{9 . 9} \mathbf{- 3 9 . 9}$ & $\mathbf{3 9 . 9}-\mathbf{6 9 . 9}$ & Above 70 \\
\hline Trawl net & 2.66 & 3.67 & 5.05 & 8.23 \\
Fish seine net & 7.60 & 14.81 & 19.60 & 28.11 \\
Anchovy seine net & 5.80 & 9.74 & 15.00 & 29.50 \\
Shellfish collection & 1.47 & & & \\
\hline
\end{tabular}

The Malaysian fishing boats are categorised into a number of classes. B class goes to all Trawlers and Fish Purse Seiners less than 40 GRT. The boats under this class are expected to be operating above 5 nautical miles from shore. However, during the monsoon season, these boats can apply for an additional special license, which allows the trawlers under this class to operate within 5 nautical miles, for them to haul prawn near shore. Trawlers and seiners between 40 and 70 GRT are under C class whose operational area is above 12 nautical miles from shore. The boats under this class which are considered as medium large boats are able to withstand rougher weather condition. During monsoon season, unlike class B boat, they are not qualified to haul near shore. Above 70 GRT, the trawlers, seiners and also drift netters are under class $\mathrm{C}$, which are classified as deep-sea vessel. Class $\mathrm{C} 2$ vessels usually operate in Exclusive Economic Zone (EEZ). The minimum distance allowed for these deepsea vessels is 30 nautical miles from shore and every fishing trip normally takes about 2 weeks.

\subsection{WIND \& WAVE PATTERN AND STATISTICS}

Situated near the Equator, Peninsular Malaysia experiences two Monsoons a year. Between March and July, the wind blows in the Southwest direction and brings wet weather to the West Coast. Since the Straits of Malacca is shielded by the Sumatra landmass, the sea is relatively mild, and interruption to the fishing activities is minimal. However, for the East Coast, the Northeast Monsoon that strikes between the month of November and February brings heavy rain to the East Coast, resulting in floods on land. It also creates heavy sea in the South China Sea, hindering fishing activity.

In order to study the wind and wave pattern of East Coast of Malaysia, the wind and wave data were obtained from the Division of Marine Meteorology and Oceanography, Malaysian Meteorological Service (MMS) [2-4]. The wave data was collected from results of numerical wave prediction model, GONO. GONO, an acronym from Golven Noordzee is the numerical wave prediction model used operationally to forecast wind sea and swell at the South China Sea by MMS and described by Yeong [6]. The model has been validated by comparison with observed and measured data from oil platforms as well as merchant ships participating in the Voluntary Observing Ships (VOS) Programme. 


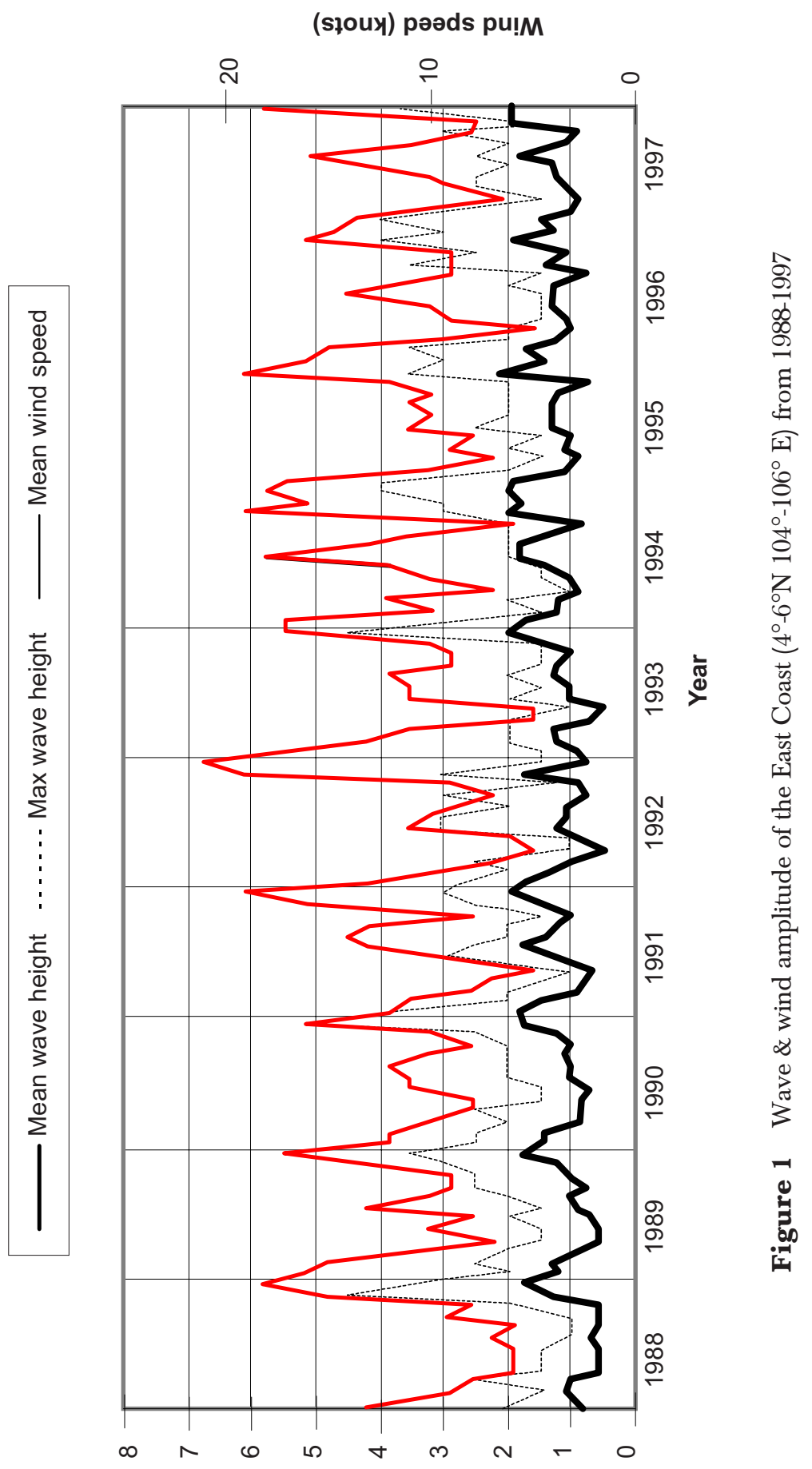

(u) ұч6!әч әлем 
The data obtained for ten years from 1988-1997 are plotted in Figure 1. It clearly shows that the wave and wind amplitudes during monsoon, from November to February, are usually higher than the other months. The plot of wave amplitudes shows $3 \mathrm{~m}$ is normal during monsoon period and that the maximum wave height recorded in that location seldom exceeds $4 \mathrm{~m}$. Normally, the maximum wave height during non-monsoon period is less than $2 \mathrm{~m}$, except in 1991 and 1992, which reached $3 \mathrm{~m}$. The mean amplitudes have a close relation with the maximum values. A commonly quoted value is about 1.6 times the significant waves, however, it might vary from 1.4 to 1.8 , sometimes even 2 times the significant waves, as shown by Engvall and Engstrom [7].

\subsection{WEATHER EFFECTS ON FISHING BOATS AND THE INDUSTRY}

\subsection{Effect on the Operability of Fishing Boats}

Heavy weather will induce boat motions and boat motions have an obvious impact on the ability to fish. Ship motions in three-dimensional sea are very complex but can be broken down into six degrees of freedom relative to three mutually perpendicular co-ordinates axes through the ship's centre of gravity. The three rotational oscillatory motions are rolling, pitching and yawing, whereas the three translatory oscillatory motions are surging, swaying and heaving. Gazi and Hussain [8] stated that a rough seaway will lead to unfavourable consequences such as seasickness, capsizing of the vessel, decreasing the forward speed, disturbing the operation of the ship's plant and flooding of the deck and damage to the hull. In addition, the difficulties associated with entering and leaving fishing ports during monsoon prevent most small boats from operation.

Tupper [9] gave six categories of motion that interfere with the operation of fishing, or causing the fishing boat to stop fishing at sea. These are danger to the vessel, gear does not fish, and vessel cannot stay on gear, loose gear on deck, and water on deck and motion impact on crews' ability to work. The most frequent reasons for stopping fishing as cited by the New England fishermen surveyed by Tupper are "gear does not fish", "vessel cannot stay on gear", "crews get jerked around" and "exhaustion from fighting motion".

The effect of boat motions on fishing gear efficiency was quantified by Enerhaug et al. [10] who demonstrated that vertical motions of the vessel affects the spread of the trawl doors, and produces vertical movement of the doors thus lifting them on and off the bottom. This causes adverse effects on the efficiency of trawling.

\subsection{Effect on Fishing Effort and Landing}

Fish landings throughout 1996 are shown in Figure 2. Considering the effect of weather downtime to the fish landings of Peninsular Malaysia, the landings of marine 


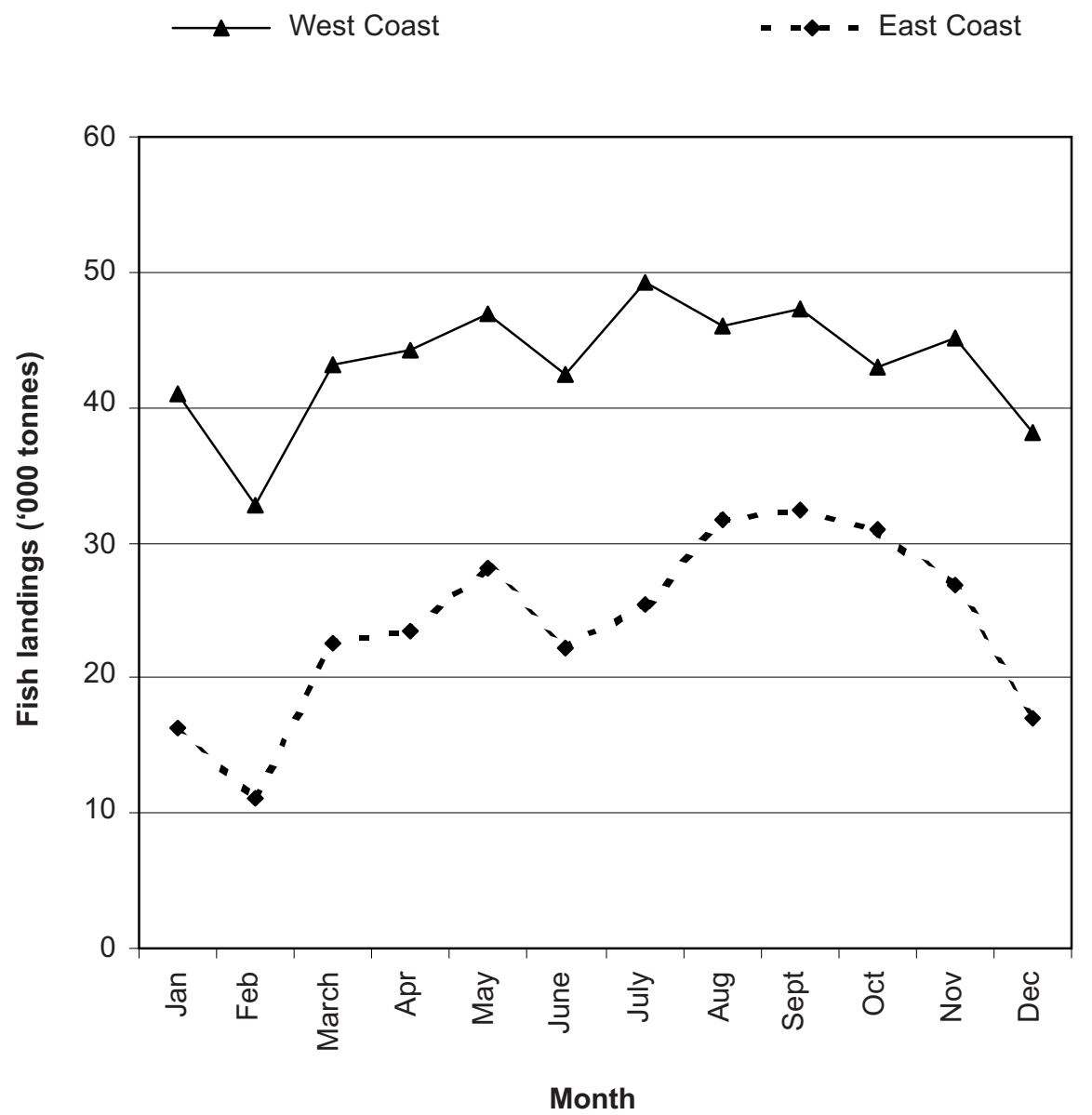

Figure 2 Fish landing of Peninsular Malaysia by month in 1996 [1]

fish in February were lowest for both the East Coast and West Coast. With the exception of February, the fish landings for the West Coast were maintained at an average level of 45000 tonnes throughout the year. However, for the East Coast, the maximum catch occurred in the month of August-September and after that, the landings dipped as a result of monsoon until February, which was the lowest point. Fish landings during June and July were also low since the sea water during that period was too clear for fishing. The landings trend of the West Coast followed the trawler landings, while for East Coast, the purse seiner.

To better present the relationship between the wave height and the landings of fish, the landings of the East Coast and Terengganu are plotted in Figure 3, together with the mean wave height from GONO, together with strong wind and wave warning from MMS [3]. It is clear that when the mean wave height increased, the fish landings decreased. Again, it can be seen that the effect of monsoon on fish landings started 


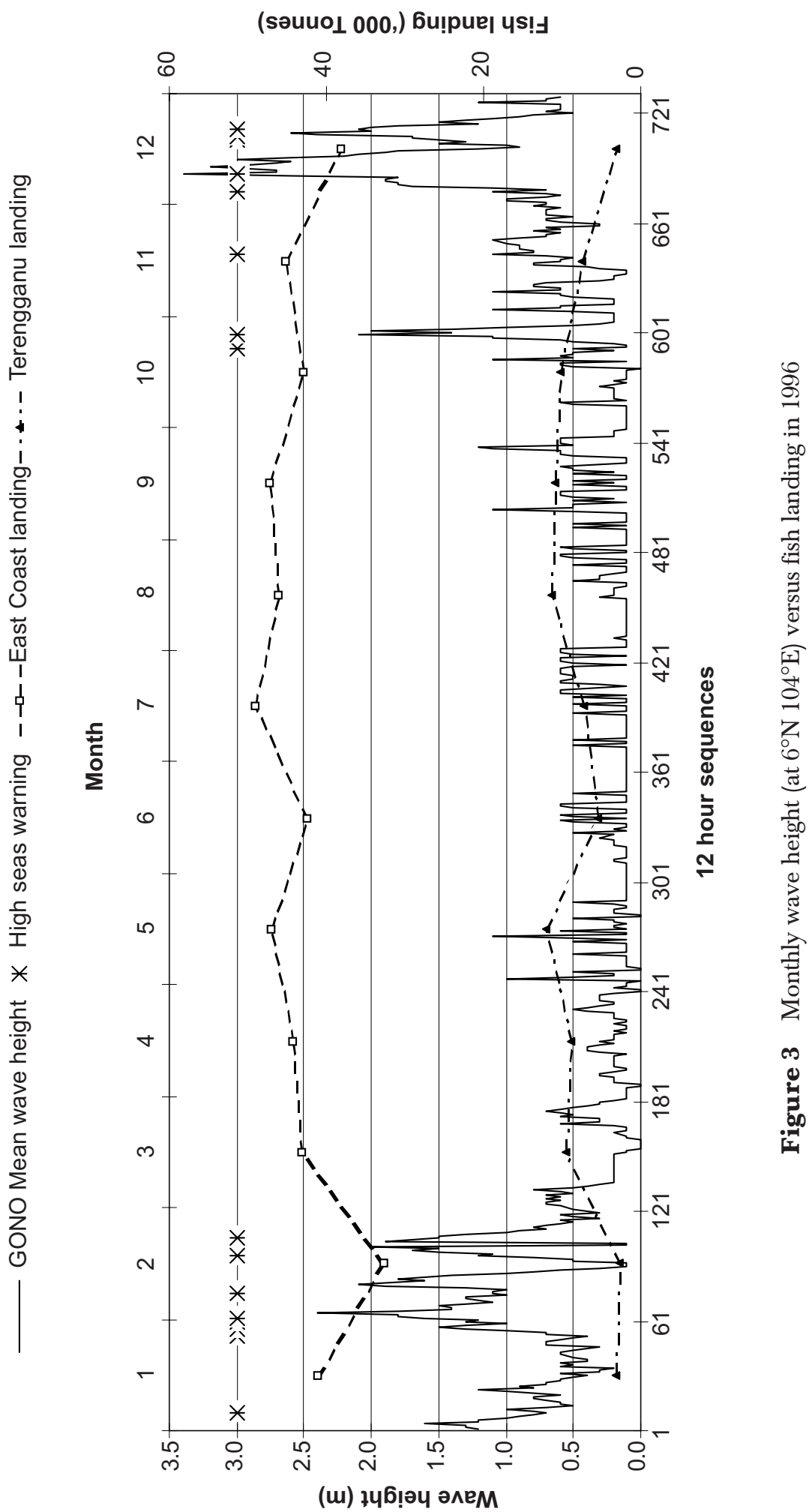


in November and ended by February. For non-monsoon season, landings for the months of June and July were low even though the wave heights were not that high. In these two months, the water was too clear for successful fishing.

\subsection{EFFECT ON FISH AVAILABILITY AND PRICE}

This section will look into the availability of fish throughout the year and the corresponding price. Figures 4 and 5 show the landing of major fish type of trawler and seiner by month respectively. The main species being trawled are Biji Nangka (Parupenues pleurospilus), Kerisi (Nemipterus japonicus), Mengkerong (Saurida tumbil), Selar Kuning (Selaroides leptolepis), Pari (Gymnura poecilura), prawn and squid. The purse seiners, being mainly employed in the East Coast, mainly land Kembong (Rastrelliger kanagurta), Tongkol (Thunnus tonggol), Selar (Alepes melanoptera ), Selayang (Decapterus maruadsi), and Tamban (Sardinella fimbriata).

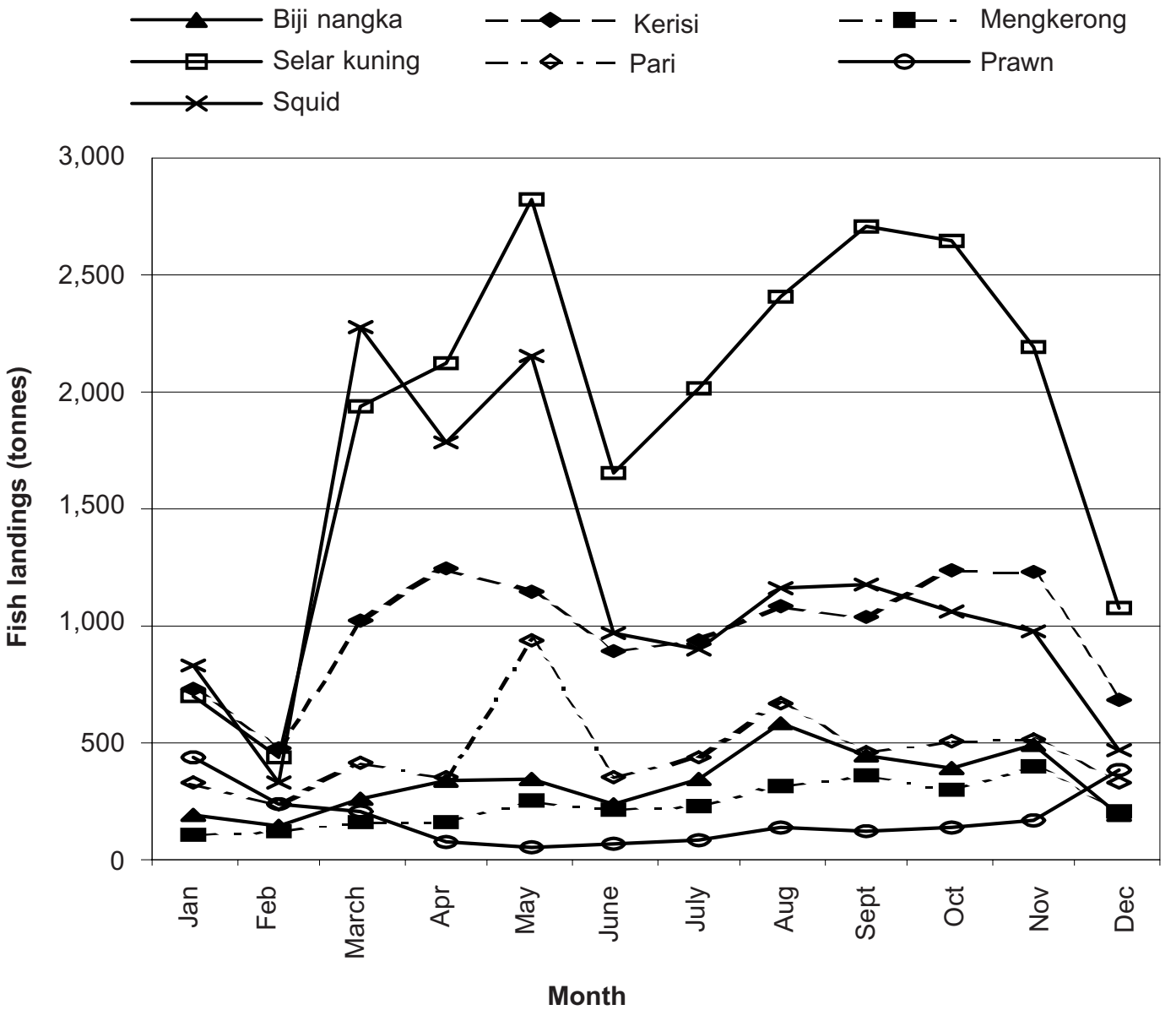

Figure 4 Landings of major fish types of trawler by month for the East Coast of Malaysia in 1996 


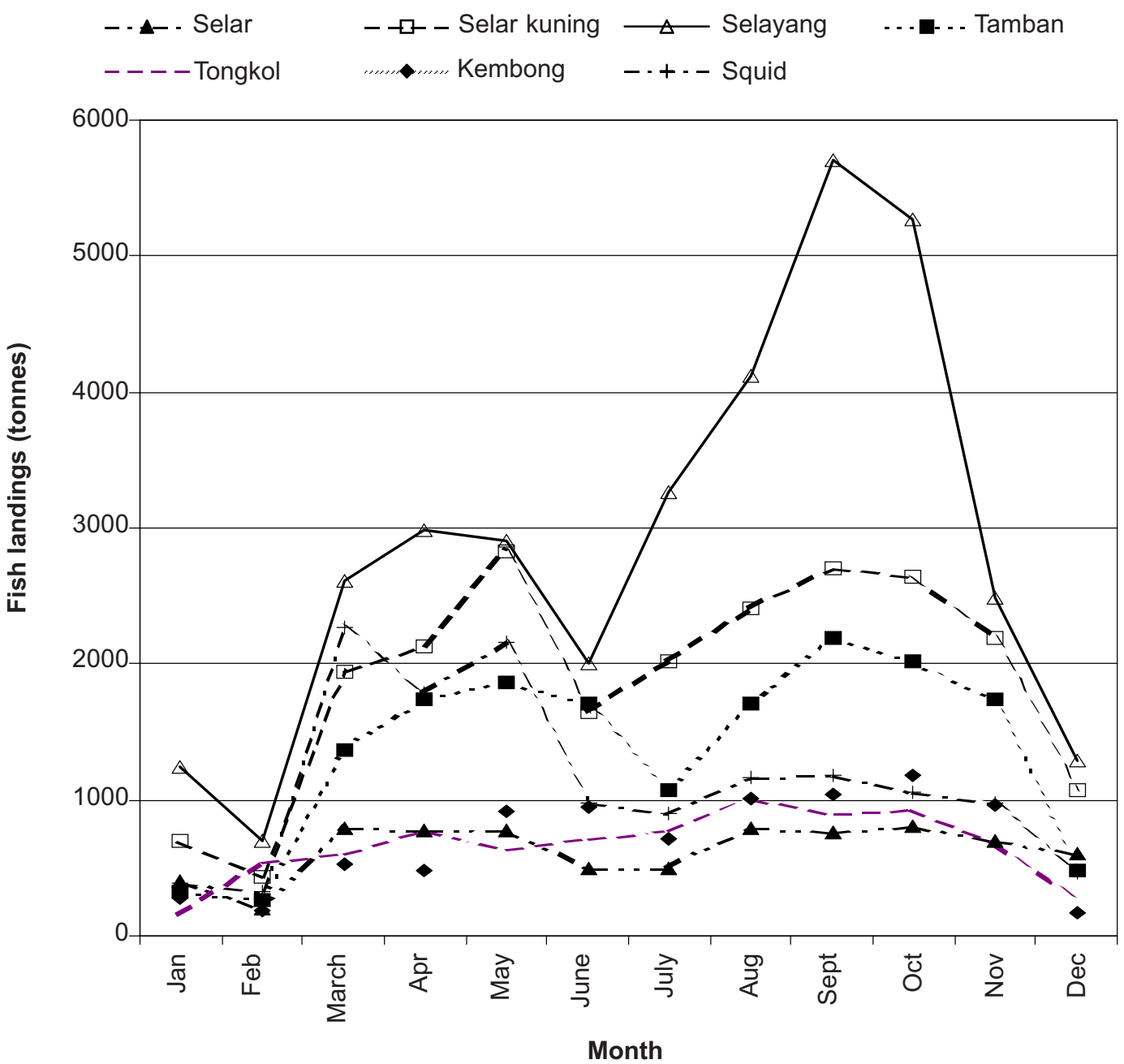

Figure 5 Landings of major fish types of fish purse seiner by month for the East Coast of Malaysia in 1996

Almost all of the landings have the pattern similar to the total landing, which was low during monsoon period, except for 'prawn' whose landing increased during the monsoon period in December to March. During the monsoon season, the strong current under sea surface carried all the prawns that usually stay at the seabed or hide beneath coral stone nearer sea surface, hence easier to be hauled by a trawler. With a special licence that is only valid for the monsoon season, the B Class trawler will be allowed to operate within 5 nautical miles from shore. Moreover, drift nets fishing boats will be allowed by Fisheries Department to convert to trawlers to haul prawns. Thus the number of boats hunting for prawn increased, leading to an increase in prawn landing during the monsoon season. 


\subsection{EFFECT ON FISHERMEN ACTIVITY AND INCOME DURING MONSOON}

Figures 6 and 7 based on the data from [5] show activities of both commercial and traditional fishermen during the monsoon season. For commercial fishermen, only $31 \%$ of them continued fishing, probably those who owned large fishing boats. The percentage of traditional fishermen continuing fishing activities was even lower at only $25 \%$.

Considering the fish price [1], the ex-vessel prices of fish were almost the same throughout the year in Peninsular Malaysia, as shown in Figure 8. In this circumstance, during the downtime, the fishermen were not paid extra. Therefore, with dwindling catch, their income is expected to be lower.

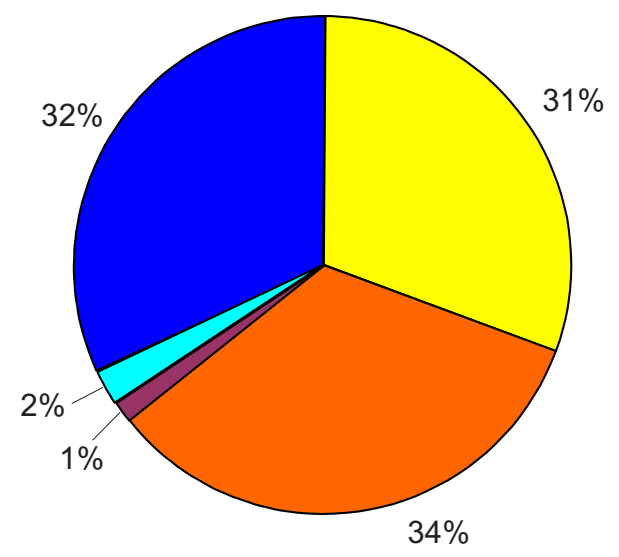

$\square$ Continue fishing

Repairing net

Farming

Doing bussiness

Others

Figure 6 Activity of East Coast commercial fishermen during monsoon

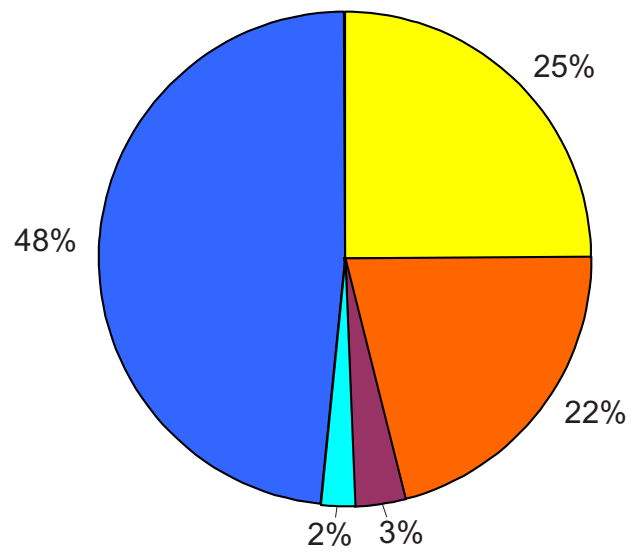

Continue fishing

Repairing net

Farming

Doing bussiness

Others

Figure 7 Activity of East Coast traditional fishermen during monsoon 


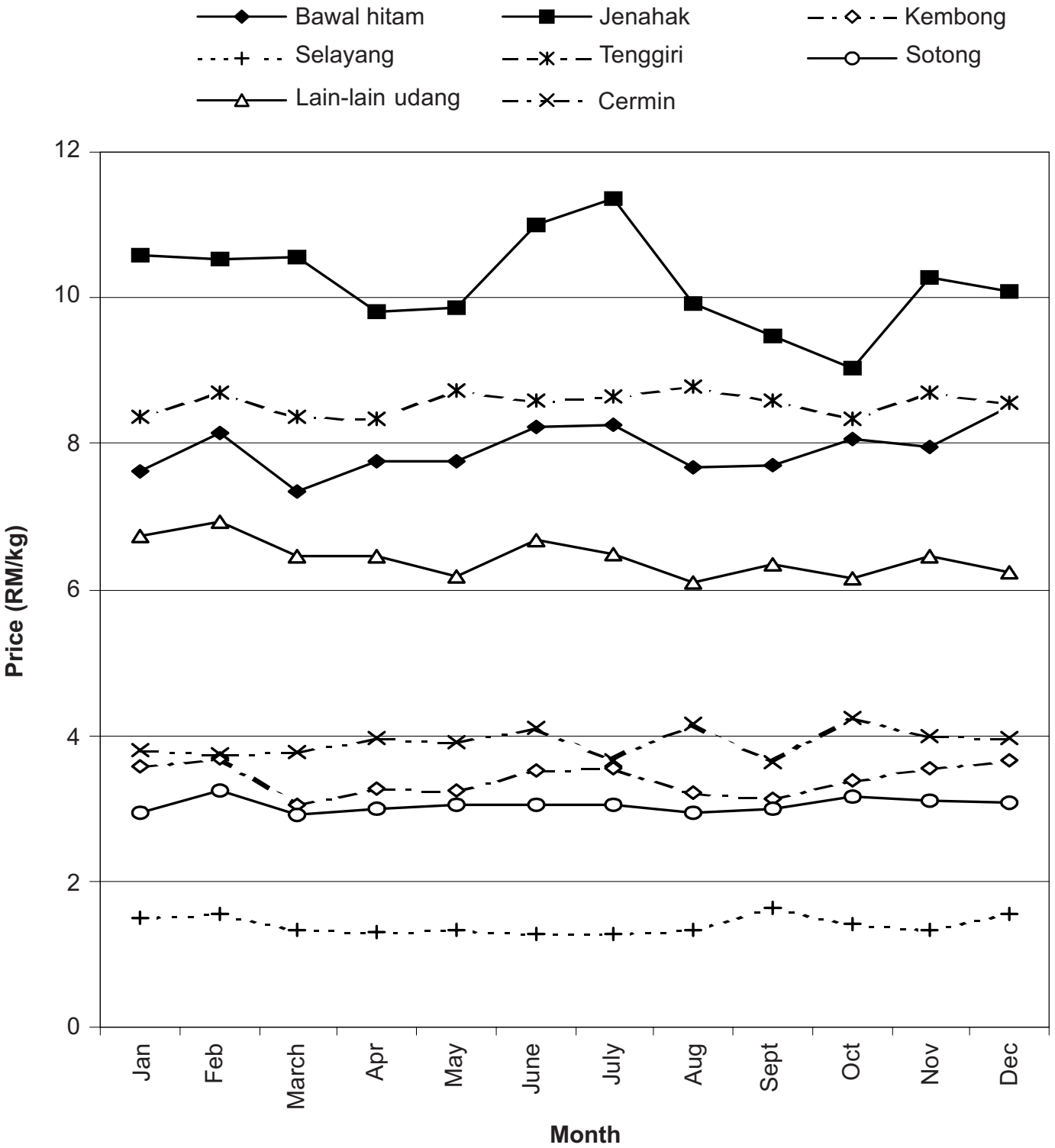

Figure 8 Monthly average ex-vessel prices of fresh fish

Tables 5 and 6 show the mean income of fishermen in different categories during normal and monsoon period taken from [5]. Note that the changes in the mean income for the West Coast between two different periods are small, whereas the changes are quite significant for the fishermen in the East Coast. For commercial and traditional skippers in the West Coast, the reduction in the mean monthly income is 3 and 5\% respectively. This compares with the income reduction between 9 to $32 \%$ for the East Coast states. 
Table 5 Mean monthly income during normal period

\begin{tabular}{|c|c|c|c|c|c|c|c|c|c|c|}
\hline \multirow[b]{2}{*}{$\begin{array}{l}\text { (All value } \\
\text { in } R M \text { ) }\end{array}$} & \multicolumn{5}{|c|}{ Commercial } & \multicolumn{5}{|c|}{ Traditional } \\
\hline & Skipper & Owner & $\begin{array}{c}\text { Skipper/ } \\
\text { owner }\end{array}$ & Crew & Diver & Skipper & Owner & $\begin{array}{c}\text { Skipper/ } \\
\text { owner }\end{array}$ & Crew & Diver \\
\hline \multicolumn{11}{|c|}{ West Coast } \\
\hline Mean value & 1186 & 3641 & 1456 & 594 & - & 624 & 597 & 675 & 498 & - \\
\hline \multicolumn{11}{|l|}{ East Coast } \\
\hline Kelantan & 573 & 5067 & 2316 & 424 & - & 419 & 417 & 412 & 319 & 290 \\
\hline Terengganu & 906 & 3443 & 2291 & 379 & 1394 & 553 & 648 & 551 & 352 & - \\
\hline Pahang & 1229 & 4720 & 1153 & 592 & - & 650 & 600 & 611 & 412 & - \\
\hline East Johor & 1461 & 2267 & 3400 & 693 & 600 & 630 & 619 & 547 & 443 & - \\
\hline
\end{tabular}

Table 6 Mean monthly income during monsoon period

\begin{tabular}{|c|c|c|c|c|c|c|c|c|c|c|}
\hline \multirow[b]{2}{*}{$\begin{array}{l}\text { (All value } \\
\text { in } R M \text { ) }\end{array}$} & \multicolumn{5}{|c|}{ Commercial } & \multicolumn{5}{|c|}{ Traditional } \\
\hline & Skipper & Owner & $\begin{array}{c}\text { Skipper/ } \\
\text { owner }\end{array}$ & Crew & Diver & Skipper & Owner & $\begin{array}{c}\text { Skipper/ } \\
\text { owner }\end{array}$ & Crew & Diver \\
\hline \multicolumn{11}{|c|}{ West Coast } \\
\hline Mean value & 1152 & 3594 & 1435 & 593 & - & 596 & 953 & 668 & 497 & - \\
\hline \multicolumn{11}{|l|}{ East Coast } \\
\hline Kelantan & 520 & 1700 & 1869 & 347 & - & 350 & 404 & 348 & 246 & 195 \\
\hline Terengganu & 769 & 2689 & 2053 & 232 & 1211 & 438 & 461 & 515 & 290 & - \\
\hline Pahang & 836 & 4720 & 893 & 437 & - & 466 & 217 & 482 & 308 & - \\
\hline East Johor & 1181 & 2095 & 2890 & 642 & 600 & 463 & 502 & 467 & 340 & - \\
\hline
\end{tabular}

\subsection{CONCLUSIONS}

The result of a study on the effect of weather downtime during monsoon season to the fishing operation and fishermen's income in Peninsular Malaysia has been presented.

During monsoon season, the wave height and wind speed can rise to almost double of its calm season value. Wave heights up to $4 \mathrm{~m}$ and wind speeds up to 40 knots can occur, which certainly do not permit small and medium size boat to be operated safely.

Consequently, higher percentages of fishermen (approximately 75\% for the East Coast) cannot go to the sea during this monsoon season. This has in turn reduce significantly the amount of fish harvested during this period. Since the fish price is 
almost unchanged throughout the year, the immediate effect is the reduction of the fishermen's income. While only a small reduction is experienced by the West Coast fishermen $(3 \%-5 \%)$, the East Coast fishermen income can be reduced by as low as $32 \%$.

Thus it is clearly indicated that the weather down time during monsoon season has been significantly affecting the fishing operation and fishermen's income, especially in the East Coast area, mainly due to traditional small size and less equipped vessels which are being used. This has created a new challenge to the fishing industry (boat designer) to develop a more suitable fishing vessel that is able to withstand the heavy weather during the monsoon season.

\section{REFERENCES}

[1] Department of Fisheries Malaysia (DFM). 1996. Annual Fisheries Statistics. Kuala Lumpur: Ministry of Agriculture.

[2] Malaysian Meteorological Service (MMS). 1996. Monthly Summary of Marine Meteorological Observations. Kuala Lumpur.

[3] Malaysian Meteorological Service (MMS). 1999. GONO Wind Input and Wave Height Output Data for 1996. Kuala Lumpur.

[4] Malaysian Meteorological Service (MMS). 1999. Strong Wind and Wave Warning Records for 1996. Kuala Lumpur.

[5] Lembaga Kemajuan Ikan Malaysia (LKIM). 1998. Report on Socio-economic Research of Malaysian Fishermen 1995. Kuala Lumpur: Ministry of Agriculture.

[6] Yeong, N. H. 1996. Numerical Wave Modelling and Forecasting at the Malaysia Meteorological ServiceMarine Meteorological and Related Oceanography Activities Report 31. Proceedings of the International Workshop on Marine Meteorology. WMO/TD-No. 621.

[7] Engvall, L. O., and J. Engstrom. 1969. A Method for Selection of an Optimum Fishing Vessel for Investment Purpose. Paper presented at the International Conference on Investment in Fisheries. Rome. FAO.

[8] Gazi, M. K., and M. Hussain. 1986. A Study of the Motions of a Fishing Boat in a Seaway. Proceedings Seminar Fishing Boats Malaysia. Universiti Teknologi Malaysia. Kuala Lumpur.

[9] Tupper, C. N. 1985. Fishing and Ship Motion - Design Considerations Based on Observations of Operations. Proc. Intl. Conf. Design, Construction \& Operations of Commercial Fishing Vessel. Florida.

[10] Enerhaug, B., A. Amble, and L. Karlsen. 1993. The Influence of Vessel Motions on Efficiency and Energy Costs in Fishing. Proc. Intl Workshop on Modern Engineering Fishing Methods in Fishing Research. Rodstock. 